\title{
Narco-analysis Test: An analysis of various Judgements of Indian Judiciary
}

\author{
Ajay Kr. Barnwal ${ }^{1}$ Dr.S.N.Ambedkar ${ }^{2}$
}

\begin{abstract}
In the changing paradigm of society the individual started to search their place in the domain of comfortability and for these they want to be strong economy, strong in politics and strong in the culture. This leads a huge competition among the people and people started using newer technologies in every area so that one will always dominate others. The criminal justice system is no more different from other systems and it has also affected from new technological advancements. The deception detection test is one of the technologies which utilizes as a tool in the extraction of truth in the investigation process. It includes Narco analysis, Lie detector and brain mapping. As in present complex society numbers of new criminal activities have grown up and criminals have started using new techniques for hiding and committing crime making it very difficult for investigating agencies to solve these complex cases with traditional methods. One of the consequences is that there is great demand of new technologies in the criminal justice system. Even various experts and committees have also recommended for the use of these technologies. These technologies are not only important for investigating the crimes but also helpful in the tracking out the future criminal activities going to commit by the criminals in the society. Though there is a demand for the use of these techniques but at the same time it raises legal, ethical and some medical issues regarding use and implication of these techniques. Through this article we made an attempt to analyze the issues and some important decisions of Judiciary which greatly affected the criminal justice system in India.
\end{abstract}

Keywords: Investigation, Criminal justice system, Lie detector, Brain mapping, Narco-analysis Technique.

\section{Introduction}

To regulate society so many things are required and one most important is sound criminal justice system which can able to make society free of criminals and criminal activity. To create a crime free society it is very important that everyone should have descent heart and mind, if not so, it can only be dreamed. The Right to information Act gives right to know the information of public importance which can be demanded from offices and which is in document form but the information only known to self is very difficult to extract and becomes crucial for criminal investigation. To extract this hidden information from human mind there are scientific methods popularly known as deception detection tests (DDTs). The Narco Analysis Test is one of the methods of DDT's which currently very much in debate and has important clinical, ethical, scientific and legal implications. These days while looking the statistics of crime and strategy of criminals the use of technology in prevention and investigation of crimes become the demand of society but at the same time we cannot exempt from the consequences which could occur while using these technologies. As far as Narco Analysis Test is concerned it is conducted by injecting sodium pentothal in the body of proposed accused or subject. The amount of sodium pentothal varies from person to person but generally it is of 3 grams dissolved in $3000 \mathrm{ml}$ of distilled water and injected with the help and presence of anaesthetist intravenously along with $10 \%$ solution of dextrose over a period of three hours. This whole process is controlled by pushing the suspected person into the state of hypnotic trance and monitoring the blood pressure and heart rate continuously. The questions framed by the expert are carefully and some are being repeated and the statements made during the hypnotic trance are recorded. The technique to extract truth from suspect through narco analysis in present time may prove a big importance for the investigating agency in India where the gap between the rate of conviction and rate of accusation are very large. As stated by Dr. M.S. Rao, Chief Forensic Scientist, Govt. Of India ${ }^{3}$ :

"Forensic psychology plays a vital role in detecting terrorist cases. Narco-analysis and brainwave fingerprinting can reveal future plans of terrorists and can be deciphered to prevent terror activities Preventive forensics will play a key role in countering terror acts. Forensic potentials must be harnessed to detect and nullify their plans. Traditional methods have proved to be a failure to handle them. Forensic facilities should be brought to the doorstep of the common man. Forensic activism is the solution for better crime management."

\footnotetext{
${ }^{1}$ Research Scholar, Public policy, Law and Governance University of Rajasthan, Email-ajay3barnwal@gmail.com Mob-09887582422.

Head of Deptt. Department of Public policy, Law and Governance, Central University of Rajasthan, Bandarsindri, Emailsnambedkar@curaj.ac.in Mob-0941454801.

${ }^{3}$ Keynote address given to the $93^{\text {rd }}$ Indian science congress. See http://mindjustice.org/india2-06.htm .
} 
According to C.B. Hanscom, Author and director of the department of protection and investigation, university of Minnesota in his article refers that "more than thirty article he himself conducted under narco analysis and made more than 230 references for criminal investigation and came in the conclusion that it is missionary duty of state to promote the drug technique in the criminological activities. The potentialities and possibilities are so broad these days. ${ }^{4}$,

According to a report issued by Seattle based Brain fingerprinting Laboratories, the technology ${ }^{5}$ can be utilized to:

- Aid in the determination of individual participated in the terrorist activity directly or indirectly.

- Aid in identifying trained terrorists who has intention to commit terrorist acts in future though presently in sleeper cell and have not been active for years.

- Help in identifying people's having knowledge or training of banking, finance and other communications and who are associated with terrorist activity.

- Help to determine the individual who has leadership role in a particular terrorist organization.

Experts and forensic scientists observed that the technique like narco analysis plays very important role in extracting truth from peoples who have under suspension or anywhere linked with terrorist activity at the same time such information can be used to detect and prevent the criminal and terrorist activities. The technique is not as fair as stated by experts rather it has another face also, which puts a big question mark in the whole process. In the process of narco analysis investigating agencies or experts tries to reach directly to the mind of the individual through some chemicals such as sodium pentothal or scopolamine. These are the drugs which used to establish contact with more or less inaccessible patients. Scopolamine is an alkaloid drug and a sedative of nervous system. It has been used generally in the treatment of coccain and morphin addicted persons and as an analgesic in obstetrics so in the process of making neutralized, imagination of a human mind by injecting these dreadful chemicals and extracting truth when the person is in semi-conscious stage raises many questions on the facts. It is dreadful that even small mistake on the part of expert being human being, can pose serious threats and result the person subjected for the tests can go even in comma or sometimes even death because the dose of chemical for neutralizing the imagination of a person varies from person to person and even small variation leads serious problems. In some cases the technique has been used and the person subjected is even not in a position to speak rather only to give some specific answers so again there is confusion regarding veracity of information extracted from the subjected person. The best example is Nithari killings case in which Mohinder singh pander and Surinder Kohli were subjected for narco analysis. The information extracted was not prima facie used as evidence rather it was used only to support the existing evidence. ${ }^{6}$ On the other hand the test said to have undermined many of the fundamental rights in India enshrined in the Constitution. J. Rolin of the view that

"The practice arrogates to science an interpretive function which pertains only to law; it violates human rights and is a rape of human mind."

\section{Views of Apex Court in India}

As the narco analysis test made individual semi conscious state where he has no control over his mind or thinking and they are unable to imagine anything. It has been proved that administration of such drug may suppress the power of thinking and reasoning of person subjected. This includes interference of nervous system of individual subjected for the test and his brain has no control over his own activity. It shows that the administration of such drugs in the body of a suspected person leads playing with the life and mind of such person. Thus the test raises fundamental issues such as right to life and liberty, Human Rights and privilege against self incrimination. The apex court of India has also given variable opinion in different cases and circumstances. The narco analysis test was introduced in India in 1936 but it was first used in 2002 in Godhara Carnage Case. It was in 2004 when Bombay High Court gave judgement in Ramchandra Ram Reddy Vs. State of Maharashtra ${ }^{8}$ case, people started debating this issue. In this case main issue was whether use of scientific technology specially brain mapping and lie detector is violation of Article 20(3) or not, the Bombay High Court opines that

"No person accused of any offence shall be compelled to be a witness against himself". It provides a privilege against testimonial compulsion. The apex court made a technical distinction between a 'Statement' and a 'Testimony' and said

\footnotetext{
${ }^{4}$ C.B. Hanscom, "Narco Intrrogation," Journal of forensic sciences 1 (1956) 37-45.

${ }^{5}$ See report of brain finger laboratories available at: http://www.brainwavescience.com/executivesummery.php.

${ }^{6} \mathrm{http}: / /$ www.thehindu.com/news/national/nithari-killings-case/article4235311.ece

${ }^{7}$ J.Rolin, Police drugs, tr. L. Bendit (New, york 1952).

${ }^{8}$ MANU/MH.0067/2004
} 
"What is required to be made under compulsion by an accused is a statement. In our opinion undergoing tests targets certain framed questions which drawn by expert after treatment that the person posses certain knowledge about the crime and in relation to targeted question put before him. So no way it can be said that any stretch of imagination which end result is statement. At the most it can be call as information received or taken out from witness. In our opinion they do not violate right against self incrimination given under article 20(3) of Indian constitution." 9

In M.P.Sharma Vs. Satish Chandra ${ }^{10}$ there was a issue that Article 20(3) provides right to the person witness in courtroom and not beyond that and same issue has been raised by the respondent in the Kathi kalu Oghad case which apex court clearly observed and held that since Article 20(3) has words "to be a witness" and not "to appear as a witness" so the protection is extended to compelled evidence obtained even outside of courtroom. The privilege against self-incrimination enables the maintenance of human privacy and right to silence pronounced by the Supreme Court.

In the case of Nandini Satpathy Vs. P.L. Dani ${ }^{11}$ Supreme Court said that "No one can extract statements from the accused, who has right to silence during the course of interrogation (investigation)". It was also claimed that the right to keep silence is by the virtue of Article 20(3) of the constitution of India and section 161(2) of Criminal procedure code and same was upheld by the apex court.

In the case of Ram Jawaya Kapoor, Court clearly said that the executive power can't intrude on constitutional rights and liberty or any other rights of the person and if it is related with fundamental rights then must struck down as unconstitutional.

However, there is an argument from the investigating agencies that the Narco analysis test is used as an aid for collecting evidence and helps the investigation so it cannot amount to testimonial compulsion as given under Article 20(3). In the case of Dinesh Dalmia Vs. State ${ }^{12}$, the Madras High Court while hearing the case held that the scientific tests such as polygraph, Brain Mapping and narco analysis conducted on accused to bring out truth would not amount to breaking his silence by force.

In the case of Selvi vs State of Karnatka ${ }^{13}$, it was held by the Supreme Court of India that the results of the test cannot be admitted as an evidence even though consented by the accused because there is no conscious control is being exercised by the subject during the course of test but the court left one option that if the subject consented for the test then any material or information discovered that can be admitted under section 27 of the Indian Evidence Act, 1872. Further it was also held that according to section 25 of Evidence Act "Confession made before any police officer are not admissible as evidence before the court." Thus the court is of the view that the statements made by the subject during custody are not admissible as evidence unless same has to be cross examined or judicially scrutinized.

In the case of Rojo George Vs. Deputy Superintendent of Police ${ }^{14}$, while allowing the narco analysis test Court is of the opinion that in present day the criminals started to use very sophisticated and modern techniques for committing the crime. So the conventional method of investigation and questioning to the criminals will not be successful for solution and there is need to utilize some new techniques such as polygraph, brain mapping and narco analysis. Court also said that when such techniques used in the presence of expert then it can't be raised that the investigating agencies violated the fundamental human rights of any citizen of India.

In the case of Santokben Sharmabhai Jadeja Vs. State of Gujarat ${ }^{15}$ the court while upholding the order for conduction of Narco Analysis test on the accused Santokben Sharmabhai Jadeja, it was observed that when after exhausting all the possible alternatives there was no possibility to find out the truth or nab the criminals and it is found by the prosecuting agency that there is no further headway of investigation, they are absolutely in dark then it is necessity of such tests. On the basis of this revelation if investigating agency finds some clues or records, some statement which helps or assists for further investigation of crime then there will not be any violation of Article 20(3) of constitution of India. In the case of Dharampal Vs. State ${ }^{16}$ it was clearly said by the Apex court that the criminal justice system cannot act properly if the person living in the society would not be cooperative so it is the duty of every person to assist the state in bringing criminal justice and detecting the crime. It must be known that no one can withhold criminal information and escape from social responsibility by avoiding such information in the name of right to privacy which itself is not an absolute right.

State of Gujarat Vs. Anirudh Singh ${ }^{17}$, the Supreme Court of India held that, it is statutory duty of every witness who has knowledge of commission crime to assist the state in giving evidence and it seems justified that if a

\footnotetext{
${ }^{9}$ Ramchandra Ram Reddy Vs. State of Maharashtra, MANU/MH.0067/2004.

${ }^{10} 1954$ AIR 300 SC

${ }^{11}$ AIR 1978 Sc 1025

122006 Crl.L.J. 2401

${ }^{13}$ AIR 2010 SC 1974

${ }^{14}$ AIR 1953 SC 131

152008 Cr.L.J. 3992

${ }^{16}$ MANU/SC/0260/2003

${ }^{17}$ MANU/SC/0749/1997
} 
person is not willing to give information which is necessary for investigation then adverse impression must be taken against them and no Article 20(3) has stop to do this. In this way Supreme Court harmonised between protection given under Constitution and narco analysis.

\section{Advantages \& disadvantages of Narco Analysis in Indian criminal justice system:}

After analysing the cases of higher courts in India, it can be said that even Indian judiciary is not very much clear while in few cases court has affirmative view on the process of narco analysis but in some other cases court denied and clearly said it can't be permitted. In their judicial pronouncements the courts have given conditional utilization of process. It can be said that the judiciary took harmonious construction regarding the use of this process and given interpretation of conditional utilization so that the process absolutely could not be ignored nor it can be used in each and every cases of crime. The judiciary by giving such type of interpretation started protecting the interests of individuals as well as society. Protection from crime and maintenance of law and order is the first priority of every state which is in social interest and at the same time to maintain human dignity and human rights is also the priority of state so the conflict of social interests and individual interests can be regulated by the judiciary. By looking at the judicial pronouncements and literature, following advantages and disadvantages can be enumerated.

\section{Advantages:}

- By looking the present pathetic condition of society regarding criminals, crime rate and affected innocent people, it seems to be right time to check the ways by which this can be reduced. It can be possible by giving rich technology to the investigation agencies and Narco analysis is one of them.

- To facilitate the investigating agencies there is need to provide an option of scientific tools which can be applied when there is absolute darkness to discover evidence.

- The traditional method of extracting truth by torture is very heinous which violates the rights of individuals and it is also blot in the society.

- The process is only harmful to the body when the doses are very high which only injected in the presence of experts.

- The questions framed by the specialized person and expertise of the process so there is very less possibility to tell a lie, as indicated by many foreign and Indian writers.

- The evidence extracted through this process may be denied as reliable but it can be used to get an admissible evidence, to corroborate with other evidence or in support of other evidence.

- Mere questioning of a person by a police officer while the person is suspected in a crime and the same is voluntary statement can't reveal as incriminatory. As in Abu salem Case, he disclosed many important information and his involvement of crime.

\section{Disadvantages:}

- In the process the chemical is administered in the body of a person so the dose of the chemical decides according to physique, mental attitude and will power of the person. A wrong dose of chemical may lead to a state of coma or even death of the person.

- If the person is drug addicted one then again the process is not as much successful as needed for collecting evidence.

- Reliability of information given by the subject is also under some shadow because the subject from whom the information is collected is in semiconscious stage and hence the question of reliability of such information is being raised.

- The well known principle of criminal justice system is that the person giving information should be "well and fit' but in the narco analysis test the person is in semiconscious stage.

- Legally speaking, the constitution of India part III Article 20(3) clearly says no person shall be a witness against himself. The process may declare as a violation of fundamental rights of Constitution.

- Section 25 of Indian Evidence Act, 1872 says that the confession made by a person under police custody could not be admitted as evidence. It means there would be possibility of non-admissibility of evidence after performing the whole process.

- Under section 161 of the criminal procedure code "the police officer authorised for investigation may ask orally any question to the person aware of facts and circumstances of the case and person shall bound to answer all the question except the questions, answer of which would have a tendency to expose him a criminal charge or to a penalty or forfeiture.

Thus the Narco-analysis Test contains both advantages as well as disadvantage features. Law as a guardian of the society needs to be changed in science and technology, according to the social paradigm, ethics 
and scientific development. The developments and scientific use of such developments should be welcome step in the criminal justice system. There are other reasons which can be enumerated here:

- Our criminal justice system needs to raise capability and sophistication and for this object, there is need to include new scientific methods of investigation process.

- Society is dynamic and the crime pattern has also changed over a period of time and technological advancement made the system much more complex and requires this methods.

- In India the conviction rate is very less and crime rate is very high. The main factor responsible for this gap is poor investigation, which can only be solved through improvement in the investigation and for this reason scientific method like narco test is a must.

- Various cases like Abu Salem, Nithari case, Arun Bhatt Kidnapping case etc. the Narco Analysis was very much useful in solving the cases. Thus using this method the complex offences can be resolved.

- Now a day's criminals are going on high-tech and indulging in cyber and internet crimes. To extract truth from them with traditional method of investigation is not much effective in the criminal justice system.

- World's best investigation Agency like US had used the Narco Analysis test for extracting truth after September 11 incident and it was written by Gerald Posner that US agency also privately believes that the Supreme Court of US also implicitly approved using such test where the public safety is at risk. ${ }^{18}$ The head of Drafting Committee of the National Criminal Justice System Policy Prof. N.R. Madhavan also recommended for the utilization of scientific method in investigation process in India.

\section{Conclusion}

As the society is changing very fast, the crime pattern is also rapidly changing. In the present scenario, where the professional trained criminals started replacing the criminal with traditional investigation methods seems to be very difficult. In this situation it is needed that the investigation agencies to update the process according to the social pattern and criminal behaviour and it can be done only by adopting scientific technique in the investigation process. The Supreme Court of USA also privately approved the use of scientific technique in the investigation procedure while public safety is at risk. This is the reason the apex Court never absolutely denied the use of Narco Analysis Tests. Various committees and commissions have issued guidelines for the use of these scientific methods. On the whole Indian judiciary has consented conditional use of these tests for extracting truth. In fact, some of the laws relating to criminal justice system need amendments so that scientific methods of investigation can become part of the laws thereby they can be utilized for the benefit of the society at large and to have a crime free society.

\section{Books:}

\section{References:}

[1]. The Constitutional law of India, J.N. Pandey, 2008, $47^{\text {th }}$ Edition

[2]. Indian Constitutional law, Prof. M.P. Jain, 2008, $5^{\text {th }}$ Edition

[3]. The Law of Evidence, Ratan Lal Dhiraj Lal, 2009, $23^{\text {rd }}$ Edition

[4]. Why America Slept: The failure to prevent 9/11. Random House, Posner Gerald, 2003.

[5]. Drugs in Clinical Anaesthesia, Pramila Bajaj, 2003, $1^{\text {st }}$ Edition.

[6]. Principles of statutory interpretation, Prof. G.P. Singh, Wadhwa \& Comp. Nagpur, $20049^{\text {th }}$ Edition.

\section{Articles Referred:}

[7]. "The Concept of Narco Analysis in view of Constitutional Law and Human Rights" by Sonakshi Verma

[8]. "Narco Analysis- A study in the law of Crimes"- By Adhish Srivastava and Anubhuti Agnihotri.

[9]. Everything new is Old Again-Brain fingerprinting and Evidentiary Analogy by Alexander J. Roberts, 9 Yale J.L. \& Tech., 234 (2007)

[10]. Medical Professionals and interrogation: lies about finding the truth by A. Jesani, Ind. Jrl of Medical ethics, Oct.-Dec. 2006.

[11]. Misconceptions about narco analysis by Bannur Muthai Mohan, Ind jrl of Medical Ethics Vol.4, 2007.

[12]. Narco Analysis and its evidentiary value in India by Barcelona Panda, Practical Lawyer, 2011.

[13]. Use of modern scientific Tests in Investigation and Evidence: Mere Desperation or justifiable in Public Interest by Abhyudya Agrawal and Prithvijit Gangopadhyay W.B. NLJS L. Rev. (2009).

[14]. Narco Analysis, Torture and Democratic Rights by A. Jesani, In peoples Union of Democratic Rights, $22^{\text {nd }}$ Dr. Ramanadham Memorial Meeting, 13 (2008).

[15]. Unearthing the truth by Gaurav Dhody, Manupatra.

[16]. Truth about the truth technique, by Chandra Shekharan, Vol.2 No.1, Scholasticus Journal of National Law University, Dec.2004.

Cases:

[17]. Ramchandra Ram Reddy Vs. State of Maharashtra, MANU/MH.0067/2004

[18]. M.P.Sharma Vs. Satish Chandra 1954 AIR 300 SC

[19]. Nandini Satpathy Vs. P.L. Dani AIR 1978 Sc 1025

[20]. Dinesh Dalmia Vs. State 2006 Crl.L.J. 2401

[21]. Selvi vs State of Karnatka AIR 2010 SC 1974

[22]. Rojo George Vs. Deputy Superintendent of Police AIR 1953 SC 131

[23]. Santokben Sharmabhai Jadeja Vs. State of Gujarat 2008 Cr.L.J. 3992 
[24]. Dharampal Vs. State MANU/SC/0260/2003

[25]. State of Gujarat Vs. Anirudh Singh MANU/SC/0749/1997

\section{Websites Referred:}

[26]. www.legalserviceindia.com Last visited on 11 August,2014

[27]. www.justor.org Last visited on 12 August,2014 